Article

\title{
Experience of Urban Hospitality: An Ecological Approach to the Migrants' World
}

\author{
Louise Carlier \\ Faculty of Economic, Social and Political Sciences and Communication, Université Catholique de Louvain, \\ 1348 Ottignies-Louvain-la-Neuve, Belgium; E-Mail: I.carlier@uclouvain.be
}

Submitted: 29 March 2020 | Accepted: 29 May 2020 | Published: 31 August 2020

\begin{abstract}
This article was inspired by a collaborative action-research experience undertaken in Brussels by ARCH (Action Research Collective for Hospitality), aimed at further understanding the dynamics of hospitality and improving hospitality towards refugees, based on collaboration with actors of civil society. In a context of spreading policies of hostility and exclusion in Europe and the lack of arrival infrastructures for undocumented migrants, asylum seekers and refugees, the people tend to occupy public spaces of the city. Consequently, these spaces become the central nodes where civil society organizes the humanitarian aid and practices of hospitality and at the same time are places for interactional tensions and institutional violence. In other words, they become an urban stage where the tension between hospitality and exclusion is played out. Based on this research, our article proposes to take the urban consequences of hostility policies seriously by analyzing the ecology of the migrants' world in the city. Our aim is to understand their experience of segregation and hospitality in the urban environment-and more specifically in public spaces. Public spaces are indeed the only livable spaces for people for whom no room has been made. However, what constitutes their hospitality for migrants, i.e., their capacity to be inhabited, enters into tension with the constitutive dimensions of urban publicness (like accessibility, visibility, or urbanity). Understanding the experience of hospitality in urban public spaces for those who have no other place to live is seen as a condition as well as a means to enhance their urban inclusion.
\end{abstract}

\section{Keywords}

city; ecology; inclusion; hospitality; hostility; migration; public space; urbanity; visibility

\section{Issue}

This article is part of the issue "Cities of Inclusion-Spaces of Justice" edited by Anja Nygren (University of Helsinki, Finland) and Florencia Quesada (University of Helsinki, Finland).

(C) 2020 by the author; licensee Cogitatio (Lisbon, Portugal). This article is licensed under a Creative Commons Attribution 4.0 International License (CC BY).

\section{Introduction}

This article is inspired by a collaborative action-research experience undertaken in Brussels by $\mathrm{ARCH}$ (Action Research Collective for Hospitality), a collective launched in January 2019, which brings together researchers and practitioners with diverse profiles. The aim of the collective was to further understand the dynamics of urban hospitality and to improve the latter towards refugees. Researches were developed in close collaboration with actors of civil society-the Citizen Platform BxIRefugees, which each day welcomes hundreds of migrants present in the city-and according to some of the needs and problems that it encountered on a daily basis ( $A R C H, 2020)$.
In a context of spreading policies of hostility and exclusion in Europe (Squire, 2009) and the lack of arrival infrastructures for undocumented migrants, asylum seekers and refugees (Meeus, Arnaut, \& van Heur, 2019), these people tend to occupy public spaces in Brussels (Depraetere \& Oosterlynck, 2017). Consequently, these spaces become the central nodes where civil society organizes the humanitarian aid but are also places of institutional violence (Deleixhe, 2018; Daher \& d'Auria, 2018; Lafaut \& Coene, 2018). In other words, they become an urban stage where the tension between hospitality and exclusion is played out.

The spatial consequences of these policies of hostility thus raise a straightforward issue for the urban commu- 
nity: that of its principles and practices of reception and inclusion. To address this issue, a collaborative actionresearch based on participatory observation, mapping, ethnography, workshops and intervention was carried out in order to understand how these vulnerable groups experience the (in)hospitality of urban spaces, to give a voice to their needs related to their environment and to redesign this environment more inclusively. Berger and Carlier (2020, p. 14) describe the collective's approach as follows: "We have tried to mobilize inquiry as a tool that can contribute to the understanding of a problematic situation, to relay voices and experiences that are currently absent from the debate, and to provide resources for action."

Based on this research, our article proposes to take the urban consequences of exclusionary policies seriously by analyzing the ecology of the migrants' world in the city. The aim is to understand their experience of segregation and hospitality in the urban environmentand more specifically in its public spaces. Public spaces are indeed the only livable spaces available to people for whom no room has been made (Mitchell, 2003). However, what constitutes their hospitality for migrants enters into tension with the constitutive dimensions of urban publicness, such as accessibility, visibility, or urbanity. Understanding the experience of hospitality in urban public spaces for those who have no other place to live is seen as a condition as well as a means to enhance their urban inclusion.

\section{The Urban Consequences of Xenophobic Policies}

In Belgium, as in Europe, asylum policy has taken on xenophobic overtones. Undocumented migrants, asylum seekers and refugees are, in the discourse of the political authorities competent in this field, widely considered as unwelcome or undesirable. Hostility towards them is institutionally organized: confinement in camps that look like prisons, expulsions, police harassment and violence, among others. Although they are based on national and European rules, these policies have spatial consequences that are particularly evident in the urban environment. Cities function as "circulatory territories" (Tarrius, 1993), as informal nodes in migratory trajectories. In a context marked by the importance of migratory flows as much as by the lack of arrival infrastructures, we can observe that many cities have several urban public spaces occupied by migrants (d'Auria, Daher, \& Rhode, 2018; Sanyal, 2012).

Cities, and more specifically their occupied places, are sites where issues of hospitality and reception are concretely at stake. The obvious and visible presence of migrant populations turn these spaces into key sites for humanitarian aid and reception services set up by citizens and civil society, in the attempt to compensate for the lack of proper reception policies, in virtue of a moral duty and a principle of civic solidarity (d'Auria, Daher \& Rhode, 2018; Depraetere \& Oosterlynck, 2017; Lafaut \& Coene, 2018). At the same time, these places become hotspots for media and political attention, where institutional violence takes place on a daily basis (Mannergren, 2020). These occupied urban spaces become places where the tension between hospitality and hostility is played out.

However, there is little reflection today on the role of cities and their public spaces in issues of reception related to migration. According to Darling (2017), very little research has been undertaken at the academic level on the links between cities and "forced migration." Studies focus on the right of asylum, European borders, refugee camps or detention centers, the city appears, at best, "as a site of bordering" (Darling, 2017, p. 183). An emergent perspective considers "the city as sanctuary" based on "a culture of welcome towards asylum seekers and refugees, based on ideals of responsibility and hospitality" (Darling, 2017, p. 184) following Derrida's perspective. Darling invites us to redirect attention towards the city, because "it offers insight into the dynamics of refugee experiences" (Darling, 2017, p. 179) and it enables deeper exploration of the "political nature of urban life" (Darling, 2017, p. 186). For Darling, this implies moving beyond the framework of hospitality, in favor of that of urban citizenship. While the first focus, considered as 'management' of reception, would have little political potential through its distinction between those who receive and those who are received, the second would have a challenging and controversial dimension by proposing new ways of political belonging that undermine national categories of citizenship. The city, as the key site of the tension between 'policing' of forced migration and 'politicization' of new urban citizenship, thus deserves to be analyzed as "a space for a politics of critique relative to the state" (Darling, 2017, p. 192).

We propose to follow Darling's invitation, while taking a distance from his perspective on two points. Firstly, Deleixhe (2018) has demonstrated that the practices of hospitality developed by the citizens' platform in Brussels, bringing together citizens outraged by the reception crisis, were fully political, leading to politicization of migration issues. As proposed by Stavo-Debauge (2017), hospitality and belonging deserve to be considered together, rather than one against the other, because hospitality opens up to belonging (Stavo-Debauge, 2017, p. 15): “The stranger's arrival hangs on hospitality (given with more or less grace); belonging to the community that receives them is what is missing at first, inasmuch as they arrive as a newcomer" (Stavo-Debauge, 2017 , p. 26). This raises the question of the different hardships each has to go through, from their reception to their inclusion in the community. If the perspective of hospitality distinguishes between those who are recognized as members of the community and those who come to it, it then invites us to take into account the existing asymmetries between the former and the latter: "Those who were already there and who together have appropriated the environment for their use, see others arrive, for whom they must make room and give enti- 
tlement inside the community they formed before their arrival and without them" (Stavo-Debauge, 2017, p. 23). Therefore, this article, as its starting point, takes cities as places where issues of hospitality are concretely played out and looks at it from the experience of the migrant as a newcomer.

Secondly, analysis of the socio-spatial dynamics characterizing the issue of migration issue occurring in urban spaces deserves consideration for its own sake because it raises issues that criticism of national policies does not thoroughly address. If the city is a stage where migration issues are expressed and the place where the tension between hospitality and hostility is played out, it is relevant to understand this situation in order to address the specifically urban issues of reception and hospitality. This implies going deeper than legal and national frameworks, in other words, looking into the places themselves: "Hospitality can then be understood as a quality relating to spaces, environments and worlds, which presupposes being prepared to receive the newcomer and to take into account what he or she brings" (Stavo-Debauge, Deleixhe, \& Carlier, 2018, p. 5). These places are taken up in various redevelopment projects, which redistribute the spaces and shape their hospitable or exclusive character. Addressing the urban issue of hospitality seems even more important given the lack of indepth reflection on this issue at both the academic and political levels (Berger, 2020). In Brussels, the places occupied by migrants are located in the Northern Quarter, a railway station district which historically constituted a first settlement area for foreign residents in the city. A whole series of urban plans and programs are being developed in this area, based on several studies, diagnoses, information or participation sessions, and workshops where the migration issue is at best only marginally addressed, but always without consequence on the materiality of the city, without translation in the plans and the development of the urban fabric. While following objectives of inclusion, these policies aim, above all, to go beyond the transit character of the area and to improve the qualities of its public spaces, which are considered as dysfunctional and unsafe. However:

A railway station district such as Brussels North is structurally and by nature a place of arrival for migrants of yesterday, today and tomorrow, and must be conceived and designed as a place where it is crucial that urban hospitality can be given. (Berger, 2020, p. 209)

This is why the ARCH collective was formed, to address the migratory situation in this part of the city where it manifests itself strongly, with a view to developing a politics of urban hospitality. In this perspective, various research projects considered the experience and perspective of civil society actors and migrants on the issues at stake for hospitality. This article focuses more specifically on one of these researches (Carlier \& Printz, 2020), mobi- lizing the of human ecology approach in order to understand the experience of hospitality in urban public spaces from the migrants' point of view.

\section{The Urban Ecology of the Migrants' World}

Exploring the link between migration and the city from the perspective of urban hospitality involves investigating the very heart of the occupied spaces, where the issues of hospitality are experienced. These occupied spaces form the living environment of migrants in the city, shaped by specific socio-spatial dynamics that determine their place within it. The human ecology approach, developed by the first school of urban sociology in Chicago, seems particularly well-suited to grasp these dynamics.

\subsection{The Ecological Approach of Social Worlds}

From the perspective of human ecology, the city is an environment shaped by ecological processes that determine the spatial distribution of social groups within it (Burgess \& Park, 1925); it is "a mosaic of little worlds" (Park, 1925, p. 40). The 'ecological processes' that shape the living environment of a social worldlike segregation/mobility, isolation/hybridization, succession or dominance (Burgess \& Park, 1921; Park, 1936)are influenced by its position in economic and political orders, and by its relations of coexistence with other social worlds living in the same environment (Wirth, 1928/1980, 1945; Zorbaugh, 1929). Human ecology has been forged over the course of numerous ethnographies dealing with "social worlds" (Cefaï, 2015) that must be investigated 'from inside,' observed in situ, in order to understand their living conditions and relation to the urban environment. Chicago researchers were quite sensitive to the way members of a social world perceived and shaped their own milieu. Human ecology was particularly interested in the living conditions of marginalized social worlds, in order to better address certain social problems. Understanding these social worlds 'from inside' was understood as a tool for the resolution of these social problems, which involved grasping the perspectives of the publics concerned-in the pragmatist perspective of John Dewey (1927/1954).

Among the works and ethnographies published by the Chicago school, one seems particularly suited to approach the ecology of the migrants' world, despite the temporal and spatial gap. Written in 1923 by Nels Anderson, The Hobo is a classic work that focuses on the social world of the "homeless bohemian," "figure of the frontier" (Anderson, 1923, p. 21), characterized by their mobility, deplorable living conditions, their physical and psychological degradation, ecological segregation and social and political exclusion. Hobos were "out of place" (Anderson, 1923, p. 151): They were part of this "class of undesirables" (Anderson, 1923, p. 150) that generated hostility and suspicion, seen as "parasites" by public opin- 
ion and having no place in the community and its social life. Anderson describes Chicago as the "capital of hobos," their point of departure and arrival because of its position at the crossroads of their mobility trajectories. He analyzed the ecology of the "Hobo world," which was made up of a few places. First of all, "Hobohemia," a small area considered as a "haven of refuge" (Anderson, 1923 , p. 13) because of the large number of services organized there, necessary for their basic needs (like accommodations or dispensaries). Outside Hobohemia, the Chicago hobos lived in "jungles" set up along the railroad tracks, close to the urban center and train stations, in accessible but marginalized open spaces that functioned as "a retreat, a resort, a social center" (Anderson, 1923, p. 17). The ecological process that determined their place in the city was segregation, in the form of concentration within restricted areas, which fostered their social isolation. Segregation was the ecological translation of their social and political exclusion, of a "social order which refuses to make a place for him" (Anderson, 1923, p. 200). Decades later, Snow and Anderson (1993) investigated the social world of homelessness from a perspective inspired by human ecology and studied the strategies of control, containment and expulsion that shape the ecology of this world.

\subsection{An Ecological Approach to the Migrants' World}

Despite the distinct spatial, temporal and political contexts, the parallels with the current situation of migrants in transit in European cities, contemporary figures of the border, are striking. The ethnography carried out in the framework of ARCH on spaces of hospitality in the Northern Quarter was inspired by this approach and focused on the migrants' experience of the urban environment. This article proposes an in-depth analysis of this work, based on data collected from participatory observation; workshops and focus group with migrants, volunteers and professionals (in the humanitarian hub and in the public spaces occupied); interviews with transmigrants, civil society actors, inhabitants of the surrounding dwellings, and shop owners of the station (all passages in italics in this article are excerpts from these interviews and focus groups).

In Brussels, the core of the migrant world's ecology is Maximilian Park, which has become an occupied space since the 'migration crisis' of 2015 (Daher \& d'Auria, 2018; Depraetere \& Oosterlynck, 2017). At that time, the queue of refugees in front of the National Foreigners Office, then located along the park, gradually turned into an occupation of this square by asylum seekers. Reception centers were hastily settled to accommodate them. Even when the National Foreigners Office moved at the end of 2018, the park remained occupied, mainly by migrants in transit:

A new type of public in turn took up residence [in the Maximilian Park] from 2017: the 'transmigrants.'
This term refers to migrants in transit who only stay in Brussels for the time it takes to find a way to cross the Channel to reach Great Britain. They do not wish to apply for asylum in Belgium and are therefore neither protected by the Geneva Convention nor eligible for a place in reception centers. (Deleixhe, 2018, p. 131)

When the ARCH collective began its research, the park was thus mainly occupied by transmigrantspredominantly male, young and African-born-given the lack of arrival infrastructure with low-threshold services for the undocumented (Trossat, 2020) along with the need to be ready to leave in the middle of the night if a smuggler should give them a possibility to cross. The park constitutes a node in the migration networks, a temporary stop in the transmigrants' trajectory. They know (they hear it through the 'grapevine') that they will find humanitarian aid and various services essential for their survival: food distribution, dispatching to humanitarian services (medical, psychological and legal assistance, distribution of clothing and healthcare products, etc.) and accommodations set up by civil society (collective shelters and citizen housing), access to information (about services, possibilities to reach the UK, etc.) and so on. The park works as an intra-urban camp (although no tents are allowed), as well as a niche for humanitarian aid and civil solidarity, gathered within the citizen's platform created in 2017 and named Brussels Refugees. It is considered by transmigrants as the place where everything happens.

Until then, Maximilian Park was little used and not part of the mental map of the city dwellers; its 'public' character was primarily reinforced by the media coverage of the human drama played out there (Quéré, 2003). Residue of a major modernist project that had known some setbacks and finally failed despite the multiple expropriations that accompanied its beginnings, the park is composed of a few facilities (like a playground, sport facilities, a fountain, toilets). Until then, it was occupied by the inhabitants of the social housing towers located on its edge who used it as their backyard. It constituted a "transitional space" (Snow \& Anderson, 1993) that welcomed an economically fragile population. The park itself is located in the Northern Quarter, a railway station area that daily welcomes thousands of commuters, holds many office buildings, and historically was a first settlement area for foreign residents in Brussels (Carlier, 2016; Daher \& d'Auria, 2018). More broadly, the Northern Quarter itself functions as an "area in transition" (Burgess, 1925) housing marginalized populations (homeless people, prostitutes, undocumented, etc.). Burgess, one of the founding fathers of human ecology, defined an "area in transition" as a "port of first entry" (Burgess, 1925, p. 58) for incoming racial and immigrant groups, with a high degree of population mobility.

Maximilian Park, a 'transitional' public space located in an 'area of transition,' has thus, recently, come to be occupied by transmigrants, a population that is itself in transit; it functions as the core of their living environ- 
ment in the city. Since its occupation, the park's facilities have been diverted to meet the occupants' daily needs, and the local inhabitants have deserted it, one social world succeeding another.

The park is connected with a few other places of hospitality set up by civil society, providing services that are temporary, thus particularly fluctuating. For example, the humanitarian hub and the shelters have already had to move several times, illustrating how difficult it is to make room for this population:

This mobility...makes obvious the everyday quest for finding space and making room for solidarity as an unceasing and enduring proposition within the Northern Quarter, and this in spite of the area's undoubtable position within the geography of migration in Brussels, and Europe at large. (d'Auria, 2020, p. 58)

When we began this research (Carlier \& Printz, 2020), the Hub was located in the North Station, which was itself occupied by a large transmigrant population. In order to spare passengers from trouble caused by their presence, a specific space was then allocated to them: the 'zero space,' located in the basement of the station, which also houses the bus terminal. On the doors of this enclosed place, an indication was given to passengers: "We hope by this action to offer more safety and cleanliness in the building." Hundreds of transmigrants slept there every night on cardboards, without access to water or toilets. Every day, professionals and volunteers distributed meals, tried to help out and support them, cleaned up the space. But opening the 'zero space' was not sufficient to contain their presence and prevent it from spreading and overflowing into other areas of the station dedicated to passengers. The unrest caused by the presence of transmigrants in the station gradually led to their evacuation. Shortly after the opening of the 'zero space,' bus drivers refused to stop at the North Station for hygienic reasons, due to information related in the media about cases of infectious diseases among the transmigrant population. Although this information was quickly denied, the rumor itself created a health crisis: the staff of the regional administration in charge of cleaning the station then refused to deal with the 'zero space.' These events worsened the situation and the station was in an increasingly pitiful state. Tension increased and the situation became unbearable for all who were confronted with it. Transmigrants claimed angrily "We're not animals!" to the many journalists on the scene to follow the situation, as widely reported on daily news sites. Actors of humanitarian aid, who were trying to manage the situation (anticipating, among other things, the evacuation that seemed more and more imminent), considered it to be 'the war.' Shopkeepers at the station were also particularly worried and rebelled against the policy of letting the situation rot. They were seeing their sales revenues shrink when passengers, their potential customers, no longer stopped to shop: "People are scared because they're in droves." They listed the various nuisances caused by the presence of migrants in the station-lack of security, dirtiness, drug trafficcomplaining that "it's the jungle now, here!" The 'zero space' was closed a few days later and the police evicted the migrant population still remaining in the station. The was done in order to give the station back to commuters and in the name of public order, to use the words of the public authorities. Transmigrants therefore retreated to the Maximilian Park. As the Hub was still located in the station, its users avoided going there except for situations of necessity. The Maximilian Park, from their point of view, became the only safe space until the hub moved a month later to another location, in the same district, still close to the park.

This episode illustrates how the ecology of the transmigrants' world is recomposed according to the few places allowed to them. In any case, it is drastically limited to enclosed humanitarian aid sites that are designed in line with a principle of sanctuary: hub and shelters, largely saturated and unable to meet all needs, and to the public spaces occupied, such as Maximilian Park.

In a context of policies of hostility, public space represents one of the few possible places of living for those who are considered as 'out of place' - who have no proper place, who necessarily occupy places not prepared for them and where they should not be (Wright, 1997), and whose presence necessarily takes the form of the "overflow" (Berger, 2018). Then, as we have seen above, this occupied public space also becomes a site where the tension between hospitality and exclusion is played out. It is the place of the first practices of hospitality, of solicitude (Bidet, Boutet, Chave, Gayet-Viaud, \& Le Mener, 2015) and care, but it is also marked by institutional violence (harassment and regular police violence): "They kick us from the station. They kick us from the park. It's all the government do." According to transmigrants, the more activists, volunteers and human aid professionals there are, the more severe the police are said to be. The occupants of the park are frequently evicted by the police (one of the citizen platform's missions is to warn 'the guys' in advance of police raids) and then systematically return to it.

From the transmigrants' point of view, the park is the safest place in their ecology, all other places are frightening (Carlier \& Printz, 2020; Mannergren, 2020). In these public spaces, concentration is a tactic of safety: to be gathered is a condition of safety, to be alone is risky: "If we're all together, there is no problem, it's a safe place. If we are two, three, the police arrive, and problems." They feel unsafe as soon as they go beyond because of the threat of police control and expulsion. The passage from one place to another (i.e., from the park to the shelter) is itself perceived as a danger:

For residents of the park, mobility around the city to access a service, posed challenges to their safety due to police cracking down on their presence, albeit 
undocumented. This makes their navigation around the city limited to certain stops and locations to and from which they feel secure. (Daher, Trossat, \& Alexis, 2020, p. 51)

Their presence in the city is therefore restricted to the park and its surroundings. Massive occupation of public space is the means by which transmigrants seek to protect themselves from police violence and the risk of expulsion. From an institutional point of view, their containment in a given space, where their presence is manifest and implicitly allowed, facilitates their control, at the same time preventing their dispersion in the urban space and the nuisance that their presence could generate for other users of the city. Transmigrants, just like hobos, represent homeless people and other "undesirables," threats to "public order" (Lofland, 1998, Chapter 6), for whom containment represents "a control strategy that seeks to reduce the public visibility of the homeless and their likely interaction with other citizens by curtailing their mobility and ecological range" (Snow \& Mulcahy, 2001, p. 160).

The processes shaping the ecology of the transmigrants' world in Brussels are similar to those observed for other "classes of undesirables" (Anderson, 1923, p. 150): segregation, characterized by isolation and concentration, taking the spatial form of containment and maintained by different political strategies, expressing exclusion from a social and political order. How do transmigrants experience these processes determining their place in the city and how do they perceive the qualities of hospitality of the places they live in?

\section{Experience of Urban Hospitality}

The research conducted in the frame of $A R C H$ was devoted to the qualities of hospitality of places that are part of the transmigrants' ecology. Enclosed places, such as the humanitarian hub or the shelters set up by civil society, are perceived as places of hospitality because of their sanctuary nature, offering a place of respite for this social world, protected for a time from institutional violence and from daily hardships (Carlier \& Printz, 2020; Lemaître d'Auchamp \& Ranzato, 2020). If their hospitality stems from their disconnection from the hostile environment, what is the transmigrants' view of the qualities of hospitality of the open public spaces occupied? Let us start from the conceptualization of urban public spaces proposed by the heirs of human ecology and from what constitutes their hospitality in this perspective (Carlier, 2018), so that we can better describe the experience that they have of it.

\subsection{Accessibility, Visibility and Urbanity}

Public space is defined first and foremost by a principle of accessibility: it is a space open to all. This accessibility is understood in a logic of mobility: public space is a space of passage, favoring connectivity between territories and ensuring freedom of movement for the passerby-this accessibility being considered in its opposition to the process of segregation (Joseph, 2007, Chapter 4; Lofland, 1998 , Chapter 8). This is the basis of its "minimal hospitality" for the newcomer (Joseph, 1998, p. 93): It allows their "intrusion," because it provides everyone a "right of visit." For these authors, accessibility of public space is not only spatial, it is also a matter of perception and visibility: Characters, uses, practices and discourses are visually accessible, subject to the gaze of everyone. The visibility of public spaces, where differences are manifest, is linked to a principle of "civil inattention" specific to the order of civility regulating relations in public. It is defined by Goffman (1963, p. 84) as follows:

What seems to be involved is that one gives to another enough visual notice to demonstrate that one appreciates that the other is present (and that one admits openly to having seen him), while at the next moment withdrawing one's attention from him so as to express that he does not constitute a target of special curiosity or design.

It is by virtue of this accessibility, both spatial and visual, that public space is the place that hosts urbanity, initially defined by Simmel $(1908 / 2004)$ as a form of sociability specific to the city, characterized by social distance and physical proximity; and then by Wirth (1945) as a set of social attitudes in a urban context of density and heterogeneity. Urbanity is at the core of the "public realm" hosted by urban life, which Lofland defined as follows: "The public realm is constituted of those areas of urban settlements in which individuals in copresence tend to be personally unknown or only categorically known to one another" (Lofland, 1998, p. 9). These relations of copresence between strangers, limited and episodic, are guided by principles of interaction specific to the public order that include civil inattention, cooperative mobility and civility towards diversity (Lofland, 1998, Chapter 2). For Lofland, these principles, specific to the public realm, support the development of a sense of tolerance between strangers, who live together despite their differences: "Limited, segmental, episodic, distanced links between self and other may constitute the social situations that both allow and teach civility and urbanity in the face of significant differences" (Lofland, 1998, p. 242). These principles allow for copresence between strangers by ensuring privacy, dis-attention and avoidance (Lofland, 1998, p. 34), conditions of the hospitality of the public space for everyone regardless of their differences.

\subsection{The Transmigrant's Experience of Publicness and Hospitality}

Transmigrants' experience of urban public space is that of an inversion of its constitutive dimensions, at the same 
time redefining what constitutes its qualities of hospitality. They represent the 'passerby' par excellence, a figure characterized by its mobility. The city is only a step along their road, where they are in transit. However, they are also the ones who are denied 'rights of visit' and freedom of movement, who find themselves trapped in a waiting situation, in a hostile environment. As mentioned, "it is a security risk to move into the unknown and the ambiguous....Migrants are on the move and they have learnt that it is unsafe to be in-between, in transit in public places" (Mannergren, 2020, p. 109). 'Out of place,' they are the ones who have nowhere to go. Consequently, the presence of migrants takes the form of occupation and fixity, which is reinforced by the way they protect themselves from violence (by being together, massively), and by the way public authorities seek to contain their presence in the city. As opposed to passage or movement, this occupation in turn limits the freedom of movement of other users-perfectly illustrated by the episode of the eviction of the migrants from the station. The station constitutes a public space perfectly defined by its qualities of accessibility, connectivity, transparency. It is designed to facilitate circulation of the user considered as a mobile individual, a passerby. The transmigrants' occupation of the station, however, enters directly into tension with the 'comfort of the user,' which justifies both their containment and their eviction from this space.

Since public space is one of the only 'livable' places for transmigrants, its qualities of hospitality therefore derive from its capacity to function as a place to acquire some resources so as to hold on while waiting to go on, for "going to chance" - in their own words-and as "a place of respite in a horrible road," as mentioned by one of the coordinator of the citizen's platform. The hospitality of the park is therefore due to its capacity to be inhabited: the presence of sheltered places to sleep under the slabs of the housing towers or at their doorways; the presence of facilities such as water points and toilets, or amenities that can be diverted to adapt to needs and uses, such as a 'spider web' from the playground diverted into a giant tumble dryer. As described and drawn (see Figure 1) by Bosmans and Daher (2020, p. 41):

The life of migrants in the park depends on the infrastructure the landscape offers. In it, they perform domestic activities, like sleeping, eating and washing; sport activities like playing football, working out or cheering; and chilling out activities like resting, socializing and walking. They appropriate everything they can find for their use.

The park also functions as a place of sociability, as a place to meet, to discuss ideas, problems, told us one of them who was in Brussels since six months before and who tried to 'go to chance' more than thirty times. Its habitability is also supported by all the services set up there by civil society and citizens, such as the distribution of food or of 'shower tickets' - services for which being in the park is often a condition of access.

However, this hospitality of the park is never a given, and it is often undermined by the political management of migration urban issues. Thus, it is not allowed to install tents and the capacity of spatial arrangement is very limited. Transmigrants consider their sleeping bags and backpacks as their home. When they sleep outdoors on cardboard, their 'right to rest' is undermined by the constant threat of control, confiscation of personal belongings, harassment or eviction by the police ("when we sleep, the police come right up to our heads and honk the horn"). This has led them to set up collective and individual strategies, like a collective watch enabling them to flee if necessary, or pepper around their sleeping bag to scare away the police dogs: "We don't really sleep," they said.
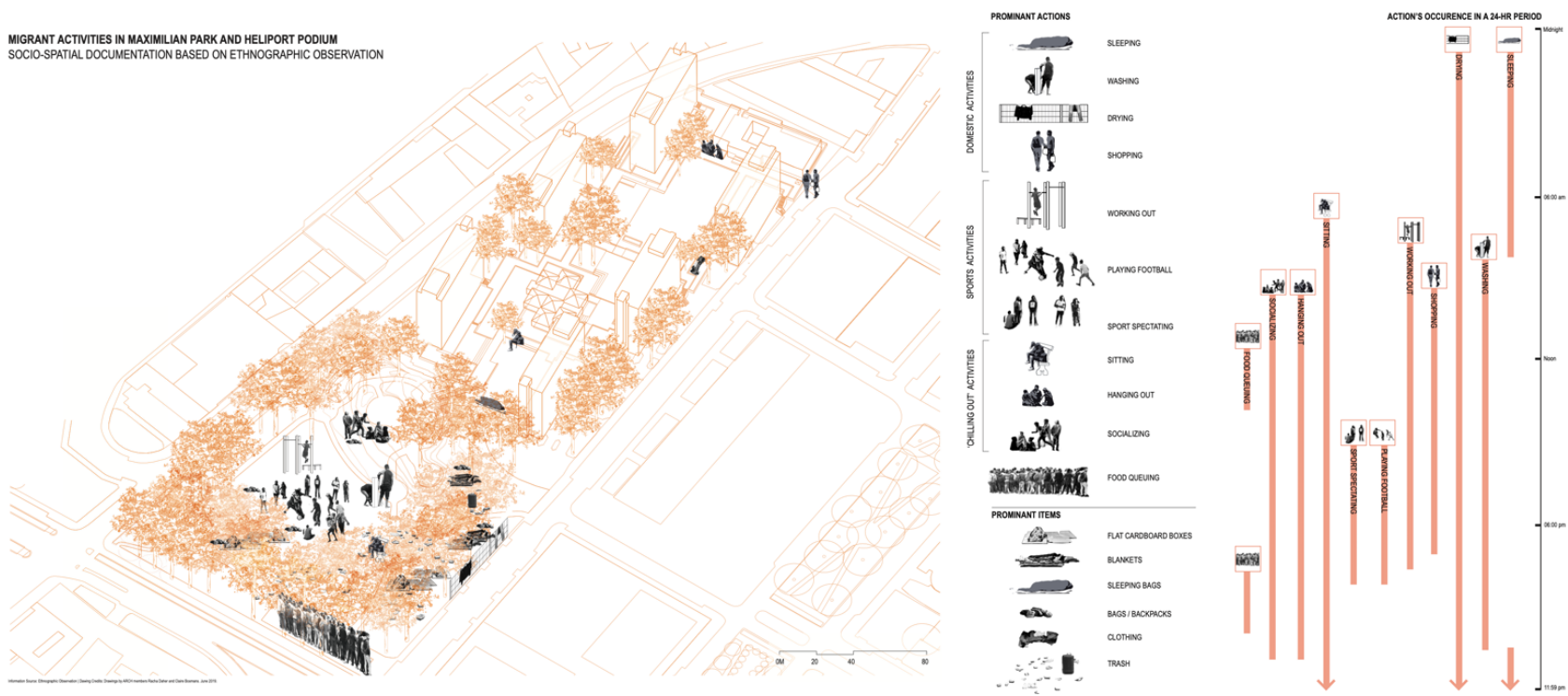

Figure 1. Migrant activities in Maximilian Park. Source: Bosmans \& Daher (2020). 
On a smaller scale, this hospitality is also undermined by changes in urban design observed since the start of the occupation. As demonstrated by Dresler (2020), benches have been removed, fences added, surveillance cameras installed, toilets added, some paths have disappeared. She points to the disappearance of "urban furniture allowing its users to rest, observe and interact," the several "elements of containment" added and "the reduction of the park's accessibility" that goes hand in hand with a decrease in its hospitality (Dresler, 2020 , p. 69). Lofland analyzed how control of uses was achieved through changes in urban design, using filtering and surveillance devices, thereby reducing the public qualities of the spaces (Lofland, 1998, Chapter 7).

Transmigrants' experience of urban public space is therefore that of an inversion of its principle of accessibility: they occupy public spaces because their freedom to come and go has been denied, so these spaces are their only place to wait and have respite. Its hospitality therefore stems from its capacity to be inhabited (Breviglieri, 2002). This is why hospitality is more than accessibility, as developed by Stavo-Debauge (2017). In this perspective:

It is not enough to 'leave the way' open to the one who comes, because it is also necessary to make room for them and give them a place, which can sometimes mean having to contain them and being able to accommodate them, for example by accommodating their differences and vulnerabilities.... In this sense, hospitality is the quality of what ensures a stay, facilitates an activity and invites someone to stay. It is also what offers support and assistance to newcomers, providing them with the necessary space and appropriate accommodations. (Stavo-Debauge et al., 2018, p. 4)

But this capacity of the environment to be inhabited weakens the constituent dimensions of urban public space. The space occupied inevitably accommodates the privacy and basic needs of transmigrants, which are, in spite of their will, public, disclosed and visible, exposed to the gaze of the others, subject to the visibility of publicness. This exposure, due to the lack of infrastructure to shelter basic needs, is perceived as a violation of privacy, and even more as a denial of dignity: "We're not animals," they contest, "Where is the democracy here? In Africa you will never sleep in the street."

Transmigrants aspire to the right to be unnoticed, to the right to 'civil inattention': In the distribution of clothes and hygiene products, the goal is to find what will best enable them to blend in and thus regain some dignity. For a coordinator of the platform in charge of this service, "it's all they have left," and "this is a question of mental health." The public exposure of privacy bars their access to the public realm and its principles of interaction. Hospitality thus requires enclosures, spaces where one may find some privacy and escape the hardships of public life:
It is in the confidence of an enclosed space that one takes care of oneself, that one takes care, to begin with, of the physical appearance that will appear outside....Whoever does not enjoy a place where, in the long term, he can take care of himself in privacy, look himself in the face and build up an image, has no resources to present himself properly to others, in public places. (Breviglieri, 2002, p. 325)

Thus, the hospitality of urban public space, from the transmigrant's point of view, is based on its capacity to be inhabited, in virtue of a freedom of movement that is denied. This hospitality comes into tension with the components of publicness, accessibility and visibility. The park's accessibility to passersby is weakenedthey bypass it, avoid it. Its hospitality is lost for the residents of dwellings close to the park, who feel disappropriated from one of the rare outdoor spaces that welcomed their own needs and uses. This generates an explosive cohabitation in this environment between its regular users and transmigrants-as described by a social worker of this area. The visibility of privacy disrupts all the principles of interaction usually at work. These spaces, where copresence is avoided due to high interactional tensions, are therefore deprived of their capacity to host the public realm. The transmigrants' access to the public realm is prevented in virtue of the way their presence must take place, which only reinforces their segregation and isolation.

\section{Conclusion: Democratic Issues of Urban Hospitality}

Because of its constitutive accessibility, public space represents the only living space for those for whom no room has been made and who are excluded from the political order. If the public character of the park allows to take place there, the ways in which migrants necessarily live in, in the form of massive occupation and containment, also inverts its public qualities. It becomes the site for tension between hospitality to the passersby or users and hospitality to the most vulnerable, stemming from its capacity to be inhabited. This disrupts the constitutive dimensions of the publicness of space: its accessibility and its urbanity.

The park maintains its public dimension by being the stage of a media and political focus, as well as the heart of practices of hospitality carried out in virtue of a moral duty and civic solidarity. However, it loses its capacity to accommodate relations of co-presence between city dwellers unknown to each other. A paradox therefore emerges: the occupation has reinforced the public character of the park, which has become the scene both of the migration crisis and of politicization for civil society. At the same time it is gradually deserted by the public realm, a realm of urban life that transmigrants-like all who are without a place for intimacy-cannot experience, because of their inability to appear in public in an appropriate form. 
Hospitality towards them requires a place capable of sheltering their privacy; it implies taking into account this vital need to inhabit the world, to occupy some space, along with other basic needs. Hospitality, in such a case, requires closure more than opening (Stavo-Debauge, 2018). This is why actors of hospitality plead for the establishment of reception infrastructures (for accommodation, help or care), whose hospitality derives from their ability to function as "inclusive enclaves" (Berger \& Moritz, 2018) or "safe havens" (Mitchell, 2003, p. 171)infrastructures providing protection and care, allowing people to regain some dignity necessary to get through the many hardships awaiting them in an environment marked by institutional hostility.

The creation of reception infrastructures, however, does not exhaust the issue of urban hospitality, given that public spaces are expected to receive those who have no other place to inhabit the world (Mitchell, 2003, p. 34). They constitute spaces whose capacity to manage with a certain disorder or unexpected presences contributes to their democratic and inclusive character (Lofland, 1998; Mitchell, 2003). This implies designing public spaces according to principles that can accommodate different situations and needs, including the need for the most excluded or vulnerable to live somewhere, to rest or retreat-in a way that does not reinforce the processes of segregation already at work for excluded people. It involves moving towards forms of spatial arrangement that enable people to live together without too many tensions, that make it possible to "put up with another's fully recognized differences" (Lofland, 1998, p. 238) in a situation of mutual accessibility and visibility.

The hospitality of urban public spaces towards excluded individuals and groups has a significance that should not be overlooked, given that principles of publicness have a political component. Hannah Arendt considered public space as a space of appearance, which is a condition for reciprocal recognition, and the emergence of a sense of community including those who are mutually visible and perceptible (Quéré, 2003, p. 81). Visibility is a fundamental dimension of urban publicness and of its political resources: Public spaces are essential to democracy as they are the only places where the excluded groups of a community make themselves visible to the members of this community (Mitchell, 2003, p. 33), and where asymmetries as well as processes of exclusion are made public: "By the visibility that [cities] impose on these processes of distancing and by the fact that the thresholds they produce are exposed, they dramatize the issue of citizenship, equal access and community belonging" (Joseph, 1998, pp. 110-111).

As such, urban public spaces represent places where the excluded may be visible, a condition for their inclusion into the community. But their hospitality towards them implies spatial arrangements allowing them to appear in public space without having to sacrifice their sense of dignity, without having to submit their privacy to the sight of the others. Only then can the visibility in urban public spaces of those excluded by the community take forms other than segregation, containment and isolation. Only then can the visibility lend to their consideration as much as their participation in public life.

\section{Acknowledgments}

I would like to thank all the members of $A R C H$, especially A. Printz, with whom the fieldwork presented in this article was conducted, and with whom the initial reflections on it were developed. I would also like to thank M. Berger, who played a key role in the ARCH project, as well as J. Stavo-Debauge and L. Pattaroni, for all the discussions and exchanges that we regularly have on these topics, and which contribute significantly to my work. Thanks also to the Metrolab team, with whom researches and discussions on the issues of urban inclusion were initiated-some of whose members are also involved in the ARCH collective.

\section{Conflict of Interests}

The author declares no conflict of interests.

\section{References}

Action Research Collective for Hospitality. (2020). Whose future is here? Searching for hospitality in the Northern Quarter. Brussels: ARCH, Metrolab Series.

Anderson, N. (1923). The hobo: The sociology of the homeless man. London and Chicago, IL: The University of Chicago Press.

Berger, M. (2018). S'inviter dans l'espace public. La participation comme épreuve de venue et de réception [Meddling in public space. Participation as a test of arrival and reception]. Sociologies. Retrieved from https://journals.openedition.org/sociologies/6865

Berger, M. (2020). Brussels-North: City policies challenged by hospitality. In ARCH (Eds.), Whose future is here? Searching for hospitality in the Northern Quarter (pp. 205-216). Brussels: Metrolab Series.

Berger, M., \& Carlier, L. (2020). Introduction. In ARCH (Eds.), Whose future is here? Searching for hospitality in the Northern Quarter (pp. 11-32). Brussels: Metrolab Series.

Berger, M., \& Moritz, B. (2018). Inclusive urbanism as gatekeeping. In M. Berger, B. Moritz, L. Carlier, \& M. Ranzato (Eds.), Designing urban inclusion (pp. 149-163). Brussels: Metrolab Series.

Bidet, A., Boutet, M., Chave, F., Gayet-Viaud, C., \& Le Mener, E. (2015). Publicité, sollicitation, intervention [Publicizing, challenges, interventions. For a pragmatist study of citizen experience]. Sociologies. Retrieved from https://journals.openedition.org/ sociologies/4941

Bosmans, C., \& Daher, R. (2020). Mapping the undocumented: Recording ephemerality in the Northern Quarter of Brussels. In ARCH (Eds.), Whose future is 
here? Searching for hospitality in the Northern Quarter (pp. 33-46). Brussels: Metrolab Series.

Breviglieri, M. (2002). L'horizon du ne plus habiter et l'absence du maintien de soi en public [The horizon of 'no longer' dwelling and the absence of selfpreservation in public]. In D. Céfaï \& I. Joseph (Eds.), L'héritage du pragmatisme. Conflits d'urbanité et épreuves de civisme [The legacy of pragmatism. Conflict of urbanity and trials of civic-mindedness] (pp. 319-336). La Tour d'Aigues: Éditions de l'Aube.

Burgess, E. W., \& Park, R. E. (Eds.). (1921). Introduction to the science of sociology. Chicago, IL: The University of Chicago Press.

Burgess, E. W., \& Park, R. E. (Eds.). (1925). The city: Suggestions for investigation of human behavior in the urban environment. London and Chicago, IL: The University of Chicago Press.

Burgess, E. W. (1925). The growth of the city: An introduction to a research project. In R. E. Park \& E. W. Burgess (Eds.), The city: Suggestions for investigation of human behavior in the urban environment (pp. 47-62). London and Chicago, IL: The University of Chicago Press.

Carlier, L. (2016). Le cosmopolitisme, de la ville au politique. Enquête sur les mobilisations urbaines à Bruxelles [Cosmopolitanism: From the city to politics. A survey on urban mobilizations in Brussels]. Brussels: Peter Lang.

Carlier, L. (2018). L'hospitalité urbaine: Une lecture croisée des approches de Park et Joseph [Hospitality: A read across Park and Joseph]. SociologieS. Retrieved from https://journals.openedition.org/ sociologies $/ 6840$

Carlier, L., \& Printz, A. (2020). Espaces d'hospitalité dans le Quartier Nord [Spaces of hospitality in the Northern Quarter]. In ARCH (Eds.), Whose future is here? Searching for hospitality in the Northern Quarter (pp. 81-90). Brussels: Metrolab Series.

Cefaï, D. (2015). Mondes sociaux. Enquête sur un héritage de l'écologie humaine à Chicago [Social worlds. A survey on human ecology's heritage at Chicago]. SociologieS. Retrieved from http:// sociologies.revues.org/4921

d'Auria, V. (2020). Tracing urban solidarity in the Northern Quarter: A cartography of mobilities and mobilizations. In ARCH (Eds.), Whose future is here? Searching for hospitality in the Northern Quarter (pp. 57-60). Brussels: Metrolab Series.

d'Auria, V., Daher, R., \& Rhode, K. (2018). From integration to solidarity: Insights from civil society organizations in three European cities. Urban Planning, 3(4), 79-90.

Daher, R., \& d'Auria, V. (2018). Enacting citizenship in an urban borderland: The case of Maximilian Park in Brussels. European Journal of Creative Practices in Cities and Landscapes, 1(1), 53-72.

Daher, R., Trossat, M., \& Alexis, V. (2020). The citizen's platform's solidarity network: Mapping services for the undocumented migrants of Maximilian Park. In ARCH (Eds.), Whose future is here? Searching for hospitality in the Northern Quarter (pp. 47-56). Brussels: Metrolab Series.

Darling, J. (2017). Forced migration and the city: Irregularity, informality, and the politics of presence. Progress in Human Geography, 41(2), 178-198.

Deleixhe, M. (2018). L'évènement de la rencontre. La Plateforme citoyenne de soutien aux réfugiés en Belgique [The event of the meeting. The citizens' platform supporting refugees in Belgium]. Esprit, 446, 130-138.

Depraetere, A., \& Oosterlynck, S. (2017). “I finally found my place": A political ethnography of the Maximilian Refugee Camp in Brussels. Citizenship Studies, 21(6), 693-709.

Dewey, J. (1954). The public and its problems. Athens, GA: Swallow Press. (Original work published 1927)

Dresler, A. D. (2020). Time-lapses of the Northern Quarter's public space. In ARCH (Eds.), Whose future is here? Searching for hospitality in the Northern Quarter (pp. 61-80). Brussels: Metrolab Series.

Goffman, E. (1963). Behavior in public places: Notes on the social organization of gatherings. New York, NY: Free Press of Glencoe.

Joseph, I. (1998). La ville sans qualités [The city without qualities]. La Tour d'Aigues: Éditions de l'Aube.

Joseph, I. (2007). L'Athlète moral et l'enquêteur modeste [The moral athlete and the modest researcher]. Paris: Economica.

Lafaut, D., \& Coene, G. (2018). Let them in! Humanitarian work as political activism? The case of the Maximilian refugee camp in Brussels. Journal of Migrant \& Refugee Studies, 17(2). 185-203.

Lemaître d'Auchamp, M., \& Ranzato, M. (2020). Moving out/fitting in: Penser ensemble le déplacement du Hub Humanitaire. In ARCH (Eds.), Whose future is here? Searching for hospitality in the Northern Quarter (pp. 145-155). Brussels: Metrolab Series.

Lofland, L. H. (1998). The public realm: Exploring the city's quintessential social territory. New York, NY: De Gruyter.

Mannergren, J. S. (2020). Searching for security. In ARCH (Eds.), Whose future is here? Searching for hospitality in the Northern Quarter (pp. 107-114). Brussels: Metrolab Series.

Meeus, B., Arnaut, K., \& van Heur, B. (2019). Arrival infrastructures: Migration and urban social mobilities. Palgrave: MacMillan.

Mitchell, D. (2003). The right to the city: Social justice and the fight for public space. New York, NY: The Guilford Press.

Park, R. E. (1925). The city: Suggestions for the investigation of human behavior in the urban environment. In R. E. Park \& E. W. Burgess (Eds.), The city: Suggestions for investigation of human behavior in the urban environment (pp. 1-46). London and Chicago, IL: The University of Chicago Press. 
Park, R. E. (1936). Human ecology. American Journal of Sociology, 42(1), 1-15.

Quéré, L. (2003). Le public comme forme et comme modalité de l'expérience [The public as a form and modality of experience]. In D. Cefaï \& D. Pasquier (Eds.), Les Sens du public. Publics politiques, publics médiatiques [Senses of the public. Political publics, media publics] (pp. 113-134). Paris: Presses universitaires de France.

Sanyal, R. (2012). Refugees and the city: An urban discussion. Geography Compass, 6(11), 633-644.

Simmel, G. (2004). Digressions sur l'étranger [The Stranger]. In Y. Grafmeyer Y. \& I. Joseph (Eds.), L'École de Chicago. Naissance de l'écologie urbaine [The Chicago School: Emergence of urban ecology] (pp. 53-60). Paris: Flammarion. (Original work published 1908)

Snow, D. A., \& Anderson, L. (1993). Down on their luck: A study of homeless street people. Berkeley, CA: University of California Press.

Snow, D. A., \& Mulcahy, M. (2001). Space, politics, and the survival strategies of the homeless. American Behavioral Scientist, 45(1), 149-169.

Squire, V. (2009). The exclusionary politics of asylum. Basingstoke: Palgrave Macmillan.

Stavo-Debauge, J. (2017). Qu'est-ce que l'hospitalité? Recevoir l'étranger à la communauté [What is hospitality? Receiving the stranger to the community]. Mon- treal: Éditions Liber.

Stavo-Debauge, J. (2018). The qualities of hospitality and the concept of 'inclusive city.' In M. Berger, B. Moritz, L. Carlier, \& M . Ranzato (Eds.), Designing urban inclusion (pp. 165-176). Brussels: Metrolab Series.

Stavo-Debauge, J., Deleixhe, M., \& Carlier, L. (2018). HospitalitéS. L'urgence politique et l'appauvrissement des concepts [HospitalitiesS. The political emergency and the impoverishment of concepts]. SociologieS. Retrieved from http://journals.openedition. org/sociologies/6785

Tarrius, A. (1993). Territoires circulatoires et espaces urbains [Circulatory territories and urban spaces]. Les Annales de la Recherche Urbaine, 59(60), 51-60.

Trossat, M. (2020). Pour des printemps hospitaliers [For hospitable springs]. In ARCH (Eds.), Whose future is here? Searching for hospitality in the Northern Quarter (pp. 91-106). Brussels: Metrolab Series.

Wirth, L. (1980). The ghetto. Chicago, IL: The University of Chicago Press. (Original work published 1928)

Wirth, L. (1945). Human ecology. American Journal of Sociology, 50(6), 483-488.

Wright, T. (1997). Out of place: Homeless mobilizations, subcities, and contested landscapes. New York, NY: State University of New York Press.

Zorbaugh, H. (1929). The gold coast and the slum. Chicago, IL: The University of Chicago Press.

\section{About the Author}

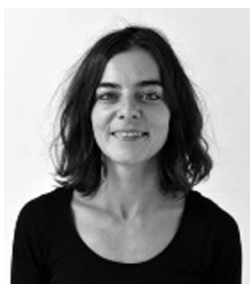

Louise Carlier is a Sociologist and Researcher at the Center for Interdisciplinary Research Democracy, Institutions, Subjectivity of the Catholic University of Louvain. She is currently a Scientific Coordinator at Metrolab.Brussels, an interdisciplinary laboratory for applied urban research. Her work focuses on urban inclusion and hospitality, in the field of urban sociology and the sociology of public problems and is inspired by human ecology and pragmatism. 